\title{
The Journal of Social Sciences Research
}

ISSN(e): 2411-9458, ISSN(p): 2413-6670

Vol. 6, Issue. 12, pp: 1001-1012, 2020

URL: https://arpgweb.com/journal/journal/7

DOI: https://doi.org/10.32861/jssr.612.1001.1012

Academic Research Publishing Group

\section{Aligning Core Competencies with Malaysia's Industry 4.0 Policy Aspirations}

\author{
Aini Suzana Ariffin (Corresponding Author) \\ Perdana Center STI Policy, Razak Faculty of Technology and Informatics Universiti Teknologi, Malaysia \\ Email: ainisuzana@utm.my
}

\section{Marlia Puteh}

Faculty of Social Sciences \& Fellow of Perdana Centre STI Policy

\section{Mah Gul Bizanjo}

University of Engineering and Technology, Khuzdar, Pakistan

\author{
Article History \\ Received: 25 November, 2020 \\ Revised: 18 December, 2020 \\ Accepted: 27 December, 2020 \\ Published: 30 December, 2020 \\ Copyright (C) 2020 ARPG \& \\ Author \\ This work is licensed under the \\ Creative Commons Attribution \\ International \\ (ㄷ) (1) CC BY: Creative \\ Commons Attribution License \\ 4.0
}

\begin{abstract}
Today, the great economists and industrialists assume that the world is on the brink of another industrial revolution, referred to as the Fourth Industrial Revolution (4IR). The digital transformation is more profound in the manufacturing sector, hence the reference to Industries 4.0 or Industry 4.0. Industry 4.0 is taken seriously at the national and organizational levels as well as at the global arena. Recognizing the urgency in aligning the Malaysian agenda with digital transformation, the Malaysian government has launched the National Industry 4WRD Strategy in 2019. This macro strategy aims to defend the national economy from a disruption in the aftermath of Industry 4.0. The Malaysian Technology Development Corporation, an agency under Ministry of International Trade \& Industry, has aligned several national policies relating to Industry 4WRD. This way, the organization will better promote local technopreneurs' growth and sustainability according to Industry 4.0 standards. This paper's objectives are twofold: 1) to gauge the outlook of management towards Industry 4.0 through interviews and; 2) to evaluate the core management competencies in the Industry 4.0 domain. A qualitative approach is utilized in analyzing the interviews with senior and middle-level managers. The paper highlights the importance of specific management skills in setting the agenda for skills growth to reposition Industry 4.0.
\end{abstract}

Keywords: Fourth industrial revolution; Industry 4.0; Smart HR 4.0; MTDC; MITI; Human capital.

\section{Introduction}

Revolutions are the outcome of continuous evolution. As humans engaged in research to overcome nature's powers, the human race is at the threshold of the Fourth Industrial Revolution 4.0 (4IR), known as the climax of social development (Wang, 2018). In his book - The Fourth Industrial Revolution, Professor Klaus Schwab stated that society is at the beginning of a revolution that profoundly affects all walks of life, including work, family life, and how we relate to each other (WEF Report, 2018). In the early 18th century, the first Industrial Revolution (IR1.0) changed the peasant society. It was characterized by high-scale mechanization in which man and animal power were replaced by water-powered steam engines, thus substituting mechanical procedures for manual labour (Ahuett-Garza and Kurfess, 2018). IR 2.0 was observed in the early 20th century in the form of rapid electrification across the globe. It was the facilitator of mass production and industrialization (Rojko, 2017). The manufacturing sector took the form of IR3.0 at the beginning of the 1970s due to the increased use of Information Communication Technology (ICT) and industry automation (Benioff, 2017). We are currently at the edge of another technological revolution, IR4.0, which is triggered by high speed emerging technologies with advanced Internet of Things (IoT) and Internet of Services (IoS) facilities focusing on smart automation of cyber-physical systems (CPS). These processes, along with decentralized control systems, are integrated with reasonable costs, high storage space, and large quantities of data processing (Ahuett-Garza and Kurfess, 2018). In this regard, Wang (2018) stated that IR4.0 would last for a minimum of 50 years. The terms Industrial Revolution 4.0 (IR4.0) and Industry 4.0 were described by the Ministry of International Trade and Industry Malaysia (MITI, 2018) as follows:

- IR4.0: "The Fourth Industrial Revolution is an overarching industrial transformation that covers every aspect of industries and economic activities including every aspect of living".

- Industry 4.0: "Industry 4.0 introduces what is referred to as "smart factory" in which cyber physical systems monitor real time physical progress of the factory and are able to make decentralized decisions. Some regard Industry 4.0 as a subset of the Fourth Industrial Revolution".

A new idea that has grown with IR4.0 and Industry 4.0 is Smart Human Resource 4.0 (Smart HR4.0). Smart HR4.0 is an innovative human resource characterized by components of Industry 4.0. namely IoT, Big Data Analytics, Artificial Intelligence (AI), and fast data networks such as 4G and 5G (Sivathanu and Pillai, 2018). The biological, physical, and technical boundaries have become blurred by the digital interconnection between 
individuals, technology, and objects. German studies have concluded that the "human workforce" will be heavily affected during this process and undergo substantial adaptation and changes (Pfeiffer, 2017).

Mustafa (2018), argued that there had been many debates on technology, automotive, and robotics. Only businesses that offer due consideration to their people, however, will take a good leap to IR4.0. He further noted that the most underestimated core asset is human capital and stressed that businesses only grow when human capital develops (Mustafa, 2018). Wang (2018), stated that manufacturing employees are likely to face threats from the following two factors, according the quality and quantity of skilled human workforce fulfilling the high-tech manufacturing positions and apprenticeship programs are not as scalable as the caliber of Industry 4.0.

Agolla (2018), described by human capital "as set of education, experience, knowledge and skills possessed by employees and that is used to create value for the success of the organization" and observed that Industry 4.0 consists of an interface in which human capital's interconnectedness with machines is the order of the day. Smart Manufacturing 4.0 features imaginative and inventive employees. This workforce is nurtured by experience, education, competence, talents, and imagination driven by their inner drive. Organizations no longer need the traditional physical workforce, as the future provides a plethora of shifts, challenging human intelligence and competence in various ways. These same characteristics are also considered critical in the transition to Smart HR4.0 for human resources.

\subsection{Industry 4.0 Establishments in Malaysia}

The Malaysian Technology Development Corporation (MTDC) is regarded as a vital element of Malaysian innovation ecosystem. This organization catalyzes the commercialization, with the aid of small start-ups and small and medium enterprises (SMEs), of R\&D results generated by various universities and research institutions. This primary mission, along with a series of value-added services such as mentoring, professional advice, and networking, is accomplished through the provision of grants, soft loans, equity support, and technology incubation centers (MTDC, 2013). The organization focuses primarily on the establishment, growth, and operation of funds and services in Malaysia to support state-of-the-art technology entrepreneurship. Its primary concern is to ensure that the application of the funds and services produced is in the right position. In addition, MTDC works with the Office of the Prime Minister and other government bodies to encourage creativity and "technopreneurship" in policy formulation.

Through continuous re-evaluation of its funding services and regular adaptability according to market conditions, MTDC is entrepreneurial in nature. It focuses on financial products, including grants, venture capital, and hybrid funds. New value-added services related to business and financial consultancy for entrepreneurs have been launched, encouraging entrepreneurs to enter the global market. The effect and importance of MTDC is observed through its contribution to the national exchequer and federal jobs. MTDC 's productive ecosystem has provided support and assistance to more than 500 technology-based enterprises, ranging from agriculture to ICT. RM1.974 billion in sales have been generated by MTDC beneficiary companies of CRDF/TAF since the 9th and 10th Malaysian Programme. Thus, creating new employment and enabling the local population to earn money. The filing of 465 Intellectual Property Rights culminated in these achievements. Given this contribution, for five years (20162020), the overall budget allocation for MTDC was RM925 million (Dahalan, 2016).

All of these contributions explicitly consider MTDC to be a significant organization in Malaysia's innovationled economic ecosystem. Given the need for industrial transformation towards Industry 4.0, MTDC's view of rising entrepreneurial technical potential has been observed repeatedly. MTDC reported that many SMEs are either in Industry 2.0 or Industry 3.0 and working on their evolution and preparation is a matter of great concern (The Edge, 2018). However, to prevent disruption in the new industrial revolution and to be Industry 4.0-ready able, SMEs have to take capacity-building steps in both production and services.

Malaysia witnessed a significant breakthrough via MTDC to develop its transition to Industry 4.0, including the soft-launch ceremony of 9 Pillars Center (Co9P) and a Memorandum of Understanding (MoU) between MTDC partners and Industry 4.0 players. The Co9P is based on a shared community model with maker labs and a coworking room, functioning as a dedicated center for Industry 4.0 (MTDC Press Release, 2018). The centre is equipped with requisite tools to enable proof-of-concept and prototypes and promote entrepreneurs' solutions to ascend the technology ladder towards Industry 4.0. A coalition of business professionals, researchers, scholars, and Industry experts was established to form an innovation-led ecosystem that will create Industry 4.0 solutions, products, and services. Co9P will include all Industry 4.0 partners and other related companies.

\subsection{Problem Statement}

The expansion of the human workforce bounds Industry 4.0's evolution of businesses. Therefore, policymakers face a race between technology advancement and human capital skills to keep up with emerging technologies. It is crucial to maximize the requisite abilities for human capital and formulate successful policies to enable the learning of those skills.

On October 31, 2018, the Malaysian Ministry of International Trade and Industry (MITI) unveiled the national Industry 4.0 policy (National Industry 4WRD policy). Also contributing to the formulation of this strategy is MTDC which considers the growth of people skills as a primary concern to avoid the detrimental effects of Industry 4.0 to the human capital of MTDC and its grant recipients, consistent with Industry 4WRD policy. There is a need for research to evaluate the appropriate MTDC management competencies. Since managers are leaders and decisionmakers, their skill development is a significant step in developing their subordinates' competencies. 
Therefore, to lift and nurture young companies and small and medium-sized enterprises, MTDC needs to improve the talents in executing both its internal and external roles. MTDC's required management skills will lead to improved decision-making, setting an agenda for new strategic planning to advance the human resource for Industry 4.0. MTDC's top-level management has also recognized the need for this research in closing the research gaps.

There is currently limited references, resources, and expertise available to support the formation and implementation of Industry 4.0 in Malaysia. MTDC's policy decisions are still in the early stages of aligning itself with Industry 4.0. This study aims to define the critical management competencies for Industry 4.0 in MTDC, thereby leading to better decision-making in the strategic plan formulation of MTDC to produce human capital competencies for Industry 4.0.

\section{Literature Review}

Industry 4.0 is a game-changer. The idea of Industry 4.0 has its roots in the 2011 German Industry 4.0 initiative, focused on the digitization of the manufacturing industry. Some countries have taken measures to quantify and deal with it due to the technological revolutions it offers. One such initiative by the German government is Industrie 4.0 (Industry 4.0), a definition put forward in a German article focusing on the 2020 High-tech Plan (Rojko, 2017). The German initiative was to redefine the manufacturing sector, a convergence of Information Technology (IT) into manufacturing, giving rise to Smart Manufacturing 4.0 or Industry 4.0. This German project aimed to place Germany's manufacturing industry as a leading consumer and supplier of digitalized production technologies worldwide.

In 2012, the Industry 4.0 project working group provided the German government with the implementation guidelines. Industry 4.0 report entitled "Securing the future of Germany as a development hub-recommended implementation for the future Industry 4.0 project") was presented at the Hannover Fair on April 8th, 2013 (Pfeiffer, 2017). The nation's political aspects, which further consider the Industry 4.0 project a critical strategic priority in Germany's economic and industrial policy, have been revived. The German Industry 4.0 project working group is regarded as the cornerstone of Industry 4.0 concerning such a meaningful experience (Schroeder, 2016).

Klaus Schwab described IR4.0 as an environment in which people switch between digital worlds and the physical world to navigate their everyday lives using advanced technology (Xu et al., 2018). Industry 4.0 or Smart Industry, a subset of IR.4.0, focuses on human and computer building block integration. These blocks are decentrally regulated embedded systems that collect real-time data for optimized production processes and products (Rojko, 2017). In addition, PSDC (2017) highlighted Industry 4.0 as “...the current trend of digital data exchange \& automation through Cyber Physical System in manufacturing technologies".

Industry 4.0 is distinguished by three main characteristics that separate it from the previous industrial revolution, namely velocity, scope, and structures. In history, the rate of current breakthroughs and new technologies is unprecedented. Industry 4.0 is expanding at an exponential rather than linear pace, disrupting almost every industry in every country. The scale of these disturbances heralds the change of the entire development, leadership, and governance structure (Leong and Kasmuri, 2017).

\subsection{Impact of Industry 4.0 on Human Capital}

The industrial revolutions have contributed to both economic change and threatened jobs in the history of humankind. However, technological progress has never been the cause of mass labor unemployment in the past 250 years (Chuah et al., 2018). Automation and digitalization have taken over human labor, but removing that line of work is not generally spelled out. As a result of industrialization, the number of workers often increases (Michael et al., 2016).

According to Hrdy (2018), routine jobs such as standard procedures, similar sequence steps, repetitive tasks, and predictable tasks are the most impactful automation on employment. Routine activities can be easily automated by converting them into computer quantification algorithms. Sorting, filing, weighing, comparing, data collecting and analysing, stock picking, and developing investment strategies are examples of such routine occupations. Cashiers, order clerks, tellers, tax preparers, cargo, freight officers, watch repairers, or telemarketers are those whose job might be easily automated.

Non-routine employment groups, on the contrary, will gain a competitive advantage. These most secure nonroutine jobs are described as jobs and tasks that are performed for the first time on an irregular basis. Examples of non-routine tasks include procedures that cannot be recorded, functions that have never been performed, beyond regular duty tasks. Besides, several routine jobs that require high levels of risk are also included as non-routine jobs.

Hrdy (2018), stressed that "not all technologies that save energy are energy-displacing". In particular, laborsaving jobs mean reducing human labor to accomplish a task. Numerous economists have reported that most inventions that displace labor end up producing more labor sources than they kill, thereby creating replacement workers to replace those lost.

Countries where labor costs are cheap regard the transition to high automation as a financial obstacle that can be resolved. Chuah et al. (2018), reported the experience of Top Glove Malaysia - one of the world's largest producers of rubber gloves. The business has gained a competitive advantage with domestic and international labor services. However, with the rise in relative labor costs, the company is moving into automation despite 25 years of successful performance. Precisely, after taking the time needed, the companies can build the potential and capacity required to adapt to the requirements of Industry 4.0. Given Industry 4.0's promising efficiency and welfare potential, the negative perceptions about Industry 4.0 tend to be misleading. This calls for appropriate policy measures to assess the skills needed for future work. Therefore, the required strategies must be planned to train the workforce to be 
competent and qualified in running automated systems and benefiting from technical advances that humankind has never seen before.

\subsection{Role of MTDC and its Challenges in Human Capital Development}

MTDC plays a crucial role in Malaysia's innovation ecosystem. Since its formation, the MTDC has played an essential role in the marketing and management of government funds. MTDC also offers comprehensive support services for technology manufacturers in advisory services, in addition, to fund management. This includes, for example, mentoring, soft-loaning, branding, fundraising, global partnership, and networking. More than 500 technology-based manufacturers that belong to heterogeneous areas ranging from agriculture to ICT have provided funding and facilities for the ecosystem developed by MTDC.

One of the roles of MTDC is promoting and assisting its grant recipients. Multiple services are introduced by MTDC to support and cultivate entrepreneurs at all stages of development. The following are other core roles performed by MTDC:

1. Symbiosis

2. Technopreneur Training Academy (TENTRA)

3. Business Funding

4. Technology Development Centres

5. Advisory and Value Added Services

Human capital is crucial in creating an accelerated shift in productivity in light of the National Industry 4WRD Policy. The country has relied on low labor costs in the past, with reduced skilled labor. MTDC must take up the task of improving its human resource to help technopreneurs to comply with Industry 4.0 requirements, and align with the National Industry 4WRD strategy. MTDC itself needs to shift to Industry 4.0 and prevent disruption to its local businesses.

The following is a set of recommendations on human capital development in the National Industry 4WRD Policy (2018) useful for MTDC to consider while formulating a strategic action plan for its talents' competency development:

- Shift Factors: The National Industry 4WRD policy identifies three shift factors to to be optimized in a balanced manner; People, Process and Technology.

- Enablers: Skills and talent are among the five specific "enablers" that determine strategies, policies and action plans, promoted in the National Industry 4WRD policy.

- Goals: One of the goals of the National Industry 4WRD policy is "to increase the number of high-skilled workers in the manufacturing sector from $18 \%$ to $35 \%$ ".

- Strategic Enablers: Skill and talent are one of the six strategic enablers of Industry 4WRD policy. This indicates that the Government aims to up-skill the existing workforce and produce talented workers for the future.

Industry 4.0 is reshaping the job landscape i.e. by making some jobs obsolete while creating new and different jobs instead. Increased skills and expertise would therefore be highly needed in the new occupational landscape in Malaysia. This will have a huge effect on Malaysia's industry, government and educational system. More standardized and improved skills would be needed by SMEs to stay competitive in the advanced Industry 4.0 scenario. It is therefore important for MTDC to build competency development programmes to reskill and upskill their current talents. This approach would also help minimize the possible effect of high levels of automation on their current work.

\subsection{Smart HR4.0 and Required Competency for Industry 4.0}

Smart Human Resource 4.0 (Smart HR4.0) emerges as Business 4.0 evolves. In the Industry 4.0 domain, Smart HR4.0 requires a new generation of employees to operate efficiently in emerging technology such as IoT, Big Data Analytics, AI, 4G and 5G fast data networks, and other Industry 4.0 components. It is fuelled by emerging technologies that, according to the current landscape of new employment, have the potential to transform end-to-end human resource management processes (Sivathanu and Pillai, 2018).

Millennial or Generation Y workers (Gen Y) are projected to represent half of the workforce by the end of 2020. These are workers born between 1980 and 2000. In the age of the internet, social media, and smartphones, both Gen Y and Gen Z (born after 2000) have grown. They have different mindsets and job requirements, including the versatility of time and space, immediate feedback, collaboration at any time and wherever, open culture, and datadriven decisions. The smart HR4.0 is more creative and efficient, powered by the work climate, facilitated by Industry 4.0 hi-tech developments (Sivathanu and Pillai, 2018).

Having the right competence will transform "replacing" Industry 4.0 technologies into "enabling" technologies for the current human capital (Chuah et al., 2018). Therefore, it is important to define the requisite competencies for Smart HR4.0 to perform effectively in Industry 4.0's work environment. A competency model in 2007 by providing competencies in four categories: personal, social/interpersonal, action-related, and domain-related competencies (Prifti et al., 2017). There are different categorizations of competencies in literature. An Industry 4.0 competency model was later developed by Hecklau et al. (2016) with four main categories: personal, social/intrapersonal, methodological, and technological competencies. In a more recent study, Grzybowska and Łupicka (2017) reported that the management competencies, from the perspective of Industry 4.0, were divided into three groups. They are technological competencies, social competencies, and managerial/personal competencies. The competencies in each 
group were chosen based on the frequency of occurrence in the recent literature. An elaboration of each category is followed.

\subsubsection{Category 1: Personal Competency}

Personal competence refers to the type of expertise, abilities and attitudes associated with an individual employee that fit well into the Industry 4.0 job domain. In a highly automated and digitised environment for routine activities, this can be seen as the ability to act in an autonomous and reflective way (Agolla, 2018). A tabulated summary of each personal competency was given in table 1 with the appropriate description and references:

Table-1. Personal Competencies with Detailed Descriptions

\begin{tabular}{|c|c|c|}
\hline Adaptability & $\begin{array}{l}\text { For agile development, personal adaptability and } \\
\text { openness to change with regard to work time, } \\
\text { work material, workplaces (virtual or physical) } \\
\text { and mindsets are prerequisite skills. It makes it } \\
\text { possible to respond quickly to business needs and } \\
\text { environmental situations. }\end{array}$ & $\begin{array}{l}\text { (Hecklau et al., 2016) } \\
\text { (Hendrick, 2017) } \\
\text { (Karre et al., 2017) } \\
\text { (Fantini et al., 2018) } \\
\text { (Agolla, 2018) } \\
\text { (Davies et al., 2011) } \\
\text { (Bermudez Milagros Diaz, 2017) }\end{array}$ \\
\hline $\begin{array}{l}\text { Creativity and } \\
\text { innovativeness }\end{array}$ & $\begin{array}{l}\text { It takes creativity and innovation to come up with } \\
\text { goods and services that generate value or bring } \\
\text { changes to life. }\end{array}$ & $\begin{array}{l}\text { (Hecklau et al., 2016) } \\
\text { (Agolla, 2018) } \\
\text { (Agolla, 2018) } \\
\text { (WEF Report, 2018) } \\
\text { (Bermudez Milagros Diaz, 2017) } \\
\text { (Aulbur et al., 2016) } \\
\end{array}$ \\
\hline $\begin{array}{l}\text { Life-long } \\
\text { learning }\end{array}$ & $\begin{array}{l}\text { The ability to cultivate a learning attitude and an } \\
\text { ethical value system that promotes continuous } \\
\text { improvement in a dynamic environment with } \\
\text { regular innovations, following the learn, un-learn } \\
\text { and re-learn concepts. }\end{array}$ & $\begin{array}{l}\text { (Hecklau et al., 2016) } \\
\text { (Karre et al., 2017) } \\
\text { (Agolla, 2018) } \\
\text { (Fantini et al., 2018) } \\
\text { (Aulbur et al., 2016) } \\
\text { (Schroeder, 2016) } \\
\end{array}$ \\
\hline Problem-solving & $\begin{array}{l}\text { Employees must be able to determine the sources } \\
\text { of problems/errors and figure out the solutions. }\end{array}$ & $\begin{array}{l}\text { (Hecklau et al., 2016) } \\
\text { (Agolla, 2018) } \\
\text { (Fantini et al., 2018) } \\
\text { (Hendrick, 2017) } \\
\text { (WEF Report, 2018) } \\
\text { (Aulbur et al., 2016) } \\
\end{array}$ \\
\hline Motivation & $\begin{array}{l}\text { Dynamic job orientations make it obligatory for } \\
\text { workers to be able to constantly change their } \\
\text { comfort zone. It takes encouragement to thrive. }\end{array}$ & (Hecklau et al., 2016) \\
\hline $\begin{array}{l}\text { Analytical } \\
\text { thinking }\end{array}$ & $\begin{array}{l}\text { Employees need analytical thinking skills to } \\
\text { remain constructive by analysing and scrutinising } \\
\text { complex procedures and vast quantities of data. }\end{array}$ & $\begin{array}{l}\text { (Hecklau et al., 2016) } \\
\text { (Schroeder, 2016) } \\
\text { (Fantini et al., 2018) } \\
\text { (Fantini et al., 2018) }\end{array}$ \\
\hline
\end{tabular}

Source: Ariffin A.S and M. Bizanjo, 2019

\subsubsection{Category 2: Social/Intra-Personal Competency}

Employees must be able to create social ties with other people, groups or organisations in social structures with in-depth connexions between various realms (virtual/physical). Interactions between different parties, such as human-machine, machine-machine, or human-human, take place in the Industry 4.0 sector. Collaboration and communication skills are therefore needed to perform the requisite interactions effectively, as per the automated and fully integrated work-environment (Agolla, 2018). Table 2 offers the relevant definition and reference of social / intra-personal competencies: 
Table-2. Social/Intra-Personal Competencies with Detailed Descriptions

\begin{tabular}{|c|c|c|}
\hline $\begin{array}{l}\text { Social/Intra-Personal } \\
\text { Competency }\end{array}$ & Description & Reference \\
\hline Communication & $\begin{array}{l}\text { Increasing virtual work and collaborative service } \\
\text { orientations requires sufficient capacity to listen, } \\
\text { present and communicate }\end{array}$ & $\begin{array}{l}\text { (Hecklau et al., 2016) } \\
\text { (Karre et al., 2017) } \\
\text { (Agolla, 2018) } \\
\text { (Fantini et al., 2018) }\end{array}$ \\
\hline Virtual collaboration & $\begin{array}{l}\text { Engagement among team members via } \\
\text { technology-mediated communication }\end{array}$ & $\begin{array}{l}\text { (Hecklau et al., 2016) } \\
\text { (Davies et al., 2011) } \\
\text { (Bermudez Milagros } \\
\text { Diaz, 2017) }\end{array}$ \\
\hline Cross-cultural skills & $\begin{array}{l}\text { It is important to consider various cultures in an } \\
\text { ethnically diverse work setting in a global scenario } \\
\text { in order to collaborate effectively. Among these } \\
\text { abilities, the ability to communicate in multiple } \\
\text { languages allows for efficient contact between } \\
\text { global partners and consumers. }\end{array}$ & $\begin{array}{l}\text { (Hecklau et al., 2016) } \\
\text { (Davies et al., 2011) }\end{array}$ \\
\hline Teamwork & $\begin{array}{l}\text { Following team rules on online joint work is a } \\
\text { serious necessity. }\end{array}$ & $\begin{array}{l}\text { (Hecklau et al., 2016) } \\
\text { (Karre et al., 2017) } \\
\text { (Schroeder, 2016) } \\
\text { (Fantini et al., 2018) } \\
\text { (Hendrick, 2017) }\end{array}$ \\
\hline Leadership skills & $\begin{array}{l}\text { Complex hierarchy tasks and increased } \\
\text { transparency require every employee to become a } \\
\text { leader in the company that can generate value. } \\
\text { This also involves improving e-leadership skills in } \\
\text { relation to the virtual environment. }\end{array}$ & $\begin{array}{l}\text { (Hecklau et al., 2016) } \\
\text { (WEF Report, 2018) } \\
\text { (Bermudez Milagros } \\
\text { Diaz, 2017) }\end{array}$ \\
\hline Emotional Intelligence & $\begin{array}{l}\text { Emotional intelligence refers to one's ability to } \\
\text { control own emotions and others' emotions for } \\
\text { sound interpersonal relationships. In a setting of } \\
\text { uniform integration, this skill is most useful. }\end{array}$ & $\begin{array}{l}\text { (Aulbur et al., 2016) } \\
\text { (WEF Report, 2018) }\end{array}$ \\
\hline Networking & $\begin{array}{l}\text { Working in a deeply interconnected value chain } \\
\text { requires skills to network and communicate } \\
\text { effectively. }\end{array}$ & $\begin{array}{l}\text { (Hecklau et al., 2016) } \\
\text { (Agolla, 2018) }\end{array}$ \\
\hline Trans-disciplinarily & $\begin{array}{l}\text { Trans-disciplinarity is about recognising concepts } \\
\text { through various disciplines, experience and skills } \\
\text { when operating on different interfaces. In social } \\
\text { structures where interactions between different } \\
\text { players take place (human to machine, machine to } \\
\text { machine, etc.), it is indispensable. }\end{array}$ & $\begin{array}{l}\text { (Agolla, 2018) } \\
\text { (Davies et al., 2011) } \\
\text { (Bermudez Milagros } \\
\text { Diaz, 2017) }\end{array}$ \\
\hline
\end{tabular}

Source: Ariffin A.S and M. Bizanjo, 2019

\subsubsection{Category 3: Technical Competency}

As the penetration of technological automation increases in industries, it is expected that the workforce will deal with established skills to use digitalization and automation in performing their routine tasks. Industry 4.0-ready workers must also have the skills to operate the technology in order to fulfil their professional duties (Hecklau et al., 2016). Technical competencies with corresponding references and definitions are shown in Table 3. 
Table-3. Technical Competencies with Detailed Descriptions

\begin{tabular}{|c|c|c|}
\hline Technical Competency & Description & Reference \\
\hline ICT Literacy & $\begin{array}{l}\text { ICT-related familiarity and ability to use } \\
\text { it safely, responsibly and ethically }\end{array}$ & $\begin{array}{l}\text { (Hecklau et al., 2016) } \\
\text { (Karre et al., 2017) } \\
\text { (Agolla, 2018) } \\
\text { (Fantini et al., 2018) } \\
\text { (Bermudez Milagros Diaz, 2017) }\end{array}$ \\
\hline $\begin{array}{l}\text { Technological } \\
\text { Innovation }\end{array}$ & $\begin{array}{l}\text { The opportunity to provide input and } \\
\text { share experience on technical goods. } \\
\text { Hence, more creative decisions on the } \\
\text { transformation of technical goods, greater } \\
\text { value production, market viability and the } \\
\text { entire supply chain can be performed. }\end{array}$ & (World Economic Forum, 2017) \\
\hline Ambiguity tolerance & $\begin{array}{l}\text { Acceptance and tolerance to unclear } \\
\text { work-related changes due to regular } \\
\text { rotation or reorientation to work-task. }\end{array}$ & $\begin{array}{l}\text { (Hecklau et al., 2016) } \\
\text { (Karre et al., 2017) } \\
\text { (Agolla, 2018) } \\
\text { (Aulbur et al., 2016) }\end{array}$ \\
\hline Troubleshooting & $\begin{array}{l}\text { Identify and troubleshoot triggers of } \\
\text { operating failures or maintenance issues } \\
\text { in a highly automated environment for the } \\
\text { smooth running of the entire system. }\end{array}$ & $\begin{array}{l}\text { (Fantini et al., 2018) } \\
\text { (Aulbur et al., 2016) }\end{array}$ \\
\hline Media Literacy & $\begin{array}{l}\text { In the IR } 4.0 \text { era, media plays a crucial } \\
\text { role. Employees must also be trained with } \\
\text { media literacy, including knowledge on } \\
\text { different types of media, skills and } \\
\text { abilities to manage multiple forms of } \\
\text { professional communication and support } \\
\text { systems. }\end{array}$ & $\begin{array}{l}\text { (Hecklau et al., 2016) } \\
\text { (Davies et al., 2011) } \\
\text { (Agolla, 2018) }\end{array}$ \\
\hline Data Management & $\begin{array}{l}\text { In Industry } 4.0 \text {, digitalization is } \\
\text { underpinned by digital data. Data must be } \\
\text { defined, captured, sorted, tracked, } \\
\text { serviced and controlled. Related and } \\
\text { value-added industrial domain knowledge } \\
\text { must be accessible in real time. }\end{array}$ & $\begin{array}{l}\text { (Ger, 2018) } \\
\text { (Fantini et al., 2018) } \\
\text { (Bermudez Milagros Diaz, 2017) }\end{array}$ \\
\hline Data Analytics & $\begin{array}{l}\text { Having the competency to assess the } \\
\text { current state of data, process and evaluate } \\
\text { information to make the best possible } \\
\text { value-added decision for the organisation. }\end{array}$ & $\begin{array}{l}\text { (Karre et al., 2017) } \\
\text { (Agolla, 2018) } \\
\text { (WEF Report, 2018) } \\
\text { (Fantini et al., 2018) } \\
\text { (Bermudez Milagros Diaz, 2017) }\end{array}$ \\
\hline Data Security & $\begin{array}{l}\text { The ability to secure data from } \\
\text { exploitative forces is the core of Industry } \\
4.0 \text {. Data security is crucial in regards to } \\
\text { in-depth integration and cooperation. }\end{array}$ & $\begin{array}{l}\text { (Hecklau et al., 2016) } \\
\text { (Karre et al., 2017) }\end{array}$ \\
\hline Entrepreneurial thinking & $\begin{array}{l}\text { Workers must represent the characteristics } \\
\text { of entrepreneurs in recognising } \\
\text { marketplace opportunities and seeking the } \\
\text { most strategic way to capitalise on them. }\end{array}$ & $\begin{array}{l}\text { (Hecklau et al., 2016) } \\
\text { (Grzybowska and Łupicka, 2017) }\end{array}$ \\
\hline Research Skills & $\begin{array}{l}\text { The ability to engage in research and use } \\
\text { credible sources of knowledge for } \\
\text { continuous learning and development. }\end{array}$ & $\begin{array}{l}\text { (Schroeder, 2016) } \\
\text { (Agolla, 2018) } \\
\text { (Bermudez Milagros Diaz, 2017) } \\
\text { (Grzybowska and Łupicka, 2017) }\end{array}$ \\
\hline
\end{tabular}

Source: Ariffin A.S and M. Bizanjo, 2019

\section{Methodology}

The first part of this paper serves as theoretical foundation by determining the key managerial competencies in the domain of Industry 4.0 through extensive literature review. Based on the research carried out by Grzybowska and Łupicka (2017), three competencies namely personal, social and technological competencies were selected. Then individual competencies were selected and backed up with relevant literature in each category.

The second part of the paper explains the importance of competencies in MTDC, from the competencies described in the light of the respondents' perspective. A semi-structured interview was designed for this purpose in order to obtain the participants' views. The top and middle-level managers appear to be the most well-informed and decision-makers; hence, they are eligible to be the respondents. As MTDC believes in multi-tasking and prefers to practise work rotations within its human capital, it was more feasible to randomly approach each sample for an interview session rather than going division-wise. In this way, instead of restricting to the current status, each 
manager could react based on their managerial experience, which could have been a lesser experience relative to the previous administrative roles he/she has been practising. Respondents were given a brief questionnaire during the interview. The questionnaire's purpose was to identify the level of top and middle-level managers' competencies according to their tasks in the MTDC. They need to respond to the personal, social, and technological competencies highlighted in the questionnaire.

The thematic method of qualitative analysis was selected as the methodology of analysis in this study, given the current study's qualitative and exploratory nature. In enhancing the understanding of the subject matter, the researchers further tabulated the brief questions to identify their mean/average. As the first phase, the researchers transcribed the interview data. Themes were built by reading and re-reading to identify the common trends emerging from the data. Next, codification was performed to reduce repetitive data and to highlight prominent data. A triangulation process was employed through the use of multiple sources of evidence. This includes numerous internal MTDC records in addition to the data obtained through interviews and systematic literature review.

\section{Results and Discussion}

The findings not only provided MTDC with a managerial perspective on Industry 4.0, but also the respondents' views on the managerial competencies needed to optimise the Industry 4.0 work domain. It is therefore the most important part of the analysis where the data obtained is summarised to highlight the significance of the findings.

\subsection{MTDC Middle-Manager's Perception towards Industry 4.0}

The interviews with the middle-managers indicate an overwhelming change to help their local technopreneurs by avoiding the disruptive technological impact brought about by Industry 4.0. One executive pointed out that: "It is something that has to be embraced because if not then there is no meaning to the word technology development to MTDC. Even if you don't like it, it will still be a part of you, unless we are not doing something not related to technology" (R4). According to World Economic Forum, a large number of world companies are still practising the conventional ways to save a lot of their workers. However, this will cause relatively greater harm in the future. But the change towards Industry 4.0 will mean that what worked in the past will no longer work in the same way in the present (Bermudez Milagros Diaz, 2017).

\subsection{Aligning MTDC's Roles with the National Industry 4WRD Policy}

Given the alarming side of Industry 4.0 with regard to technological unemployment and the disruption of existing human resources, MTDC has taken an ambitious approach towards Industry 4.0. The respondents' views were more inclined towards leveraging the potential of Industry 4.0, where innovations would add to MTDC's current authority with effective strategic planning strategies and an optimistic outlook. One of the respondents outlined his thoughts on the role of MTDC and the government's Industry 4.0 policy: "MTDC has started this Industry 4.0 before the launching of the national policy, last year we prepared our grassroots on the Industry 4.0. Normally we are parallel with the government and then we launch our hub (Co9P) to help the government to ensure that we are in the same page" (R5). Such an agenda is designed to provide MTDC with better opportunities, more competitiveness and improved performance.

According to Hrdy (2018), the impact of Industry 4.0 on established employment is negative. Complementary employment is created along with the distruptive technology, and this promotes a win-win situation. One of the middle-managers explained MTDC's approach on this subject: "To enable the company to achieve 4.0, they need to incorporate the 9 pillars. Malaysia is not ready for all the 9 pillars. Worldwide there are very few companies which can actually go with 4.0. But not in 4.0 in totality. That is the key difference in terms of MTDC's approach. Other than that, we are looking at building up all the necessary solution that is required to take the company to the next level. That is how we actually build our 4.0 strategy" (R3).

\subsection{The Impact of Industry 4.0 on MTDC's Human Capital}

The in-depth automation of Industry 4.0 has brought about impacts on several human capital dimensions of MTDC. The middle-managers has various interpretations on the impacts to the human capital development. One respondent believed that the impact is two-fold, "If you look at the Industry 4.0 drive, it will impact human capital in terms of two things. One obviously there is going to be reduction in terms of number of resources, and second is remaining resources. If to think efficiently, meaning that there will be reduction of people, but if we upgrade the people you have, the existing people, in terms of upgrading their skill sets. Those are two impacts; they will have on human capital" (R3). In a positive tone, this manager pointed out that, "It is good in a way how you are replacing all the minimum skill jobs, that do not require knowledge, it is more of repetition all that then it is a good thing in terms of companies being able to increase their efficiency and productivity so that is a good thing. And perhaps by doing that you can get more people to focus on up skilling themselves and going towards knowledge-based jobs rather than going towards low skill jobs" (R9).

However, the negative impact could not be ignored as Industry 4.0 advances technology displacement and unemployment. This MTDC manager expressed his concerned: "There would be a lot of replacements of the simple labour after new technology comes in. You used to have one man to look after one machine. But now you just need the same person and multiple machines because the machines talk to each other. Another is the indication of the breakdown before it really breaks down. So, there is a lot of efficiency there but there is also a need for the existing workers" (R4). The ultimate objective of automation and digitization is promising and fruitful. However, appropriate 
policy measures and suitable strategies are vital in enabling MTDC to perform its tasks in the era of disruptive technology.

\subsection{Competency Development for MTDC}

A learnable technology upgradation and simultaneous upgrading of the current workforce has been discussed in the literature as well as by MTDC managers for the growth of skills. This manager explained: "In MTDC, our goals are to be an enabler for Industry 4.0 for companies within our ecosystem as well as for companies outside our ecosystem; we need to be in the forefront. In saying that, most of the staff in MTDC has to be prepared and should know about Industry 4.0" (R2). Another manager warned the importance of 4.0 competencies: "There is going to be a certain percentage of jobs in the next few years are not even available now. Which means that the coming workforce, graduates and all that, may not be relevant with the knowledge which they are supposed to have, once they are ready to look for jobs and all that. So it is very important that employees or companies really monitor the Industry 4.0 even if they are not adopting it because if you want to implement something for the organization than it will involve a lot of things, cost, resources, and whether it is a priority of the company or not to adopt any part of the Industry 4.0" (R6).

Hrdy (2018) also advocated that Industry 4.0 encourages wealth generation and job creation. Therefore, in order to avoid technological unemployment and disruption of the workforce, Industry 4.0 needs to be harnessed with proper policy initiatives and implementation for the competency development of the existing workforce.

\subsection{Concerns and Planning Options for MTDC on 4.0 Competency Development}

A shift in the current comfort zone is often correlated with transition. Therefore, awareness and visibility issues related to skills development for Industry 4.0 were also raised among the managers on the subject. One respondent (R13) was specifically concerned on change management in MTDC: Internally, the biggest challenge for all of us is to bear the change. People will have to learn about change management, they will have to learn to adapt, adopt and also accept because change is never easy. Especially when you are very comfortable in your comfort zone. So how I see is that, it's going to be one of the main hurdles which all of us will go through. This is where HR [human resource] plays an important role. Maybe they should arrange for change management courses".

Chuah et al. (2018) emphasized that policy principles and agenda should not only protect the existing jobs from being outdated and unproductive due to the technological transition. Instead, it should protect the current workforce 4.0 competency development. The interview sessions demonstrated that the MTDC executives were inclined towards taking up the task of improving relevant skills rather than saving existing jobs in Industry 4.0. Participant R10 recommended the design of Portfolio Managers in MTDC's digital platform. This is his proposal: “We need to have an official platform to make available for the PMs (Portfolio Managers) to interact with Industry players to see how other agencies are doing it. And start to have interactive communications like how they are doing it and how we are doing it. It gives us the sense of ownership that how we want to improve our company. So, the more you know about how other people are doing, the more you know to establish your own process and how you want to innovate yourself and prove to the company that you need to be hired and you need to be promoted".

The need for suitable policy is pressing especially when Industry 4.0 has brought about a lot of changes. This manager communicated his concern on the need of 4.0-related policy: "I think the right policy has to be put in place especially when Industry 4.0 is something very new, so you need to have policies. But the removal of some irrelevant policy is equally important because it may constrain or delay some of the developments of the country" (R6).

A little restructuring was observed when the MTDC management changed the name of one department into an IR4.0 Department. While this department's position is not yet in line with its name, this change reflects MTDC 's tendency and agenda to take the shifts to Industry 4.0 rather than maintaining its original strategies.

\subsection{Required 4.0 Managerial Competencies to Reposition MTDC}

The determination of the necessary 4.0 management's competencies in MTDC is an important contribution to this study. Table 4 offers an overview of the outcome by showing the competencies and its detailed explanations.

Table-4. Proposed 4.0 Managerial Competencies

\begin{tabular}{l|ll}
\hline Mean & Competency \\
\hline 1 & Communication \\
\hline 1.07 & Adaptability, Creativity \& Innovation, Teamwork, Networking \\
\hline 1.14 & Analytical Thinking, Leadership Skills, Entrepreneurial Thinking \\
\hline 1.21 & Life-Long Learning \\
\hline 1.35 & $\begin{array}{l}\text { Problem Solving, Motivation, Cross-Cultural Skills, Emotional Intelligence, Trans- } \\
\text { disciplinarity, ICT Literacy, Data Analytics }\end{array}$ \\
\hline 1.42 & Data Management \\
\hline 1.5 & Ambiguity Tolerance \\
\hline 1.57 & Virtual Collaboration \\
\hline 1.64 & Media Literacy \\
\hline 1.71 & Data Security \\
\hline 1.78 & Technological Innovation \\
\hline 2.07 & Troubleshooting \\
\hline
\end{tabular}

Source: Ariffin A.S and M. Bizanjo, 2019 
Note:

Italic $\rightarrow$ Personal Competency

Bold $\rightarrow$ Social Competency

Normal Font $\rightarrow$ Technical Competency

Maximum Obtained Mean=1, indicates highest importance/requirement

Maximum Obtained Mean=2.07, indicates least importance/requirement

Increment in mean from 1 towards 2.07 indicates lower importance/requirement

MTDC's management perspectives show that communication is an essential competency where each respondent agrees that such quality is a must for a leader. The value of communication is further discussed by Prifti et al. (2017). Agolla (2018) notes that adaptability and sustainability are the most critical characteristics in the 4.0 environment. The disruptive technology setting will impact the work environment, particularly technological experience, technical expertise, computer skills, and educational technology. These research findings tally Agolla's work when all respondents viewed adaptability as the leader's most relevant competency.

All competencies are essential. However, in performing a specific role, some of the competencies are comparatively more essential than the others. In this regard, Table 5 has outlined the personal, social, and technical skills. Personal skills, followed by social skills and technical competencies, are the most relevant skills.

On the contrary, soft skills are personal qualities that allow an individual to interact effectively with other people in his environment based on his personality traits, character, attitude, and intellect. In this study, the social and personal skills competencies fall under soft skills. Bermudez Milagros Diaz (2017), revealed that soft skills would be critical in the Industry 4.0 era because this will allow the workforce to transform and become more flexible to adapt to new job domains. It will be a constant, life-long learning experience.

This study contributes to the body of literature regarding Malaysia's view on the importance of personal and social skills among middle-level managers of MTDC. The respondents agreed that personal and social skills as the most critical skills needed by MTDC for the successful performance of managerial tasks in the 4.0 work environment. In addition, the respondents also believed that the nature of work at MTDC does not necessitate managers to possess technical competency to be relevant in the 4.0 setting. MTDC is a corporation offering funds and services; the findings highlight that MTDC's core functions are non-technical, unlike manufacturing companies. Similarly, the Austrialia Industry Group (2018) also supports the result that when workers need to turn their attention to the things computers do not do but are unique to humans, technological skills would be less critical. It involves personal and social skills, such as emotional intelligence, imagination, and critical thinking.

\subsection{Recommendations}

The defined competencies were considered by most of the respondents to be sufficient for the successful performance of MTDC executives in the 4.0 Industry setting. Additional competencies were also proposed by six of the respondents as highlighted in table 5.

Table-5. Proposed Additional Competencies for MTDC in Industry 4.0 Domain

\begin{tabular}{l|l}
\hline Respondent & Recommended Additional Competency \\
\hline R2 & Financial competency, Innovation competency \\
\hline R3 & Passion \\
\hline R6 & Good command in English speaking \\
\hline R9 & Sharing of vision and information from upper management to subordinates \\
\hline R10 & Self-move for making your own place and be participative in MTDC \\
\hline R13 & Change management, Empathy \\
\hline
\end{tabular}

Source: Ariffin A.S and M. Bizanjo, 2019

The German government is the originator of the Industry 4.0 project and the representative of a global phenomenon of transition and disruption (Matthiae and Richter, 2018). Even for well-established agencies, change management is crucial in shifting towards in-depth ICT integration and higher automation. Talents are expected to adjust, embrace, and accept the modifications which challenge the limits of their current comfort zone. Therefore, it is strongly recommended that MTDC incorporate similar change management activities to address the varying stages of higher automation implementation, with appropriate strategic planning improved in change management. A beneficial initiative could be the implementation of change management courses. The department of Human Capital \& Knowledge Management (HC and KM) needs to play this vital role.

The most significant aspect was the self-awareness of Industry 4.0 and the concern of the middle-managers to share the associated experience and vision to the subordinates. As the first personnel to deal with the technopreneurs, portfolio managers (PMs) should have the essential understanding of Industry 4.0 and awareness on MTDC's strategic planning, to better facilitate the technopreneurs. The entire phenomenon of Industry 4.0 was deemed pointless if it is not addressed with awareness and change management. The growth of skills, clarity of vision and change management tools will make MTDC's transformational journey towards Industry 4.0 a smooth ride. 


\section{Conclusion}

MTDC's strategic planning direction should not only cover existing jobs. Instead, the transformation and change agenda should consider the transition to disruptive technology because Industry 4.0 has been proclaimed the gamechanger in the dynamic world of international business. Industry 4.0 may also lead to adverse challenges such as loss of work opportunities and unemployment if the requisite skills and competencies are not established and introduced to the industries. The expertise and their subsequent competencies shape the secondary data for this project. Therefore, the determination of necessary managerial competencies in the MTDC is considered a primary step in the strategic formulation to create MTDC competencies successfully. Advantageously, the outlook of MTDC executives is strong and optimistic towards Industry 4.0, but MTDC's strategic planning is still in the initial stages. This exploratory research is the first MTDC study to evaluate the critical management competencies that MTDC would need to empower the Industry 4.0 workforce. It serves as the resource for MTDC to plan the strategic agenda for the growth of human capital skills in repositioning MTDC for Industry 4.0. This project has also contributed to raising awareness and spreading information about Industry 4.0 within MTDC's workforce during various research stages.

Humans are less likely to be substituted by machines any time faster. This is because personal competencies consist mostly of soft skills unique to humans and cannot be replaced by machines. Concentrating more on reskilling and upskilling human competencies will surely assist us to be better human beings in the Industry 4.0 era. MTDC's roles will remain critical to the country and government in the Industry 4.0 era on the human competencies.

\section{Acknowledgment}

The authors wish to gratefully acknowledge Universiti Teknologi Malaysia for funding this research under the TDAR Grant, Under UTM-TDR2.4 (T1): Entrepreneurship Education Policy within Industrial Professional Practice Workforce Vote:QK130000.3555.053G10.

\section{Reference}

Agolla, J. E. (2018). Human capital in the smart manufacturing and industry 4.0 revolution. Digital Transformation in Smart Manufacturing, 2: 41-58.

Ahuett-Garza, H. and Kurfess, T. (2018). A brief discussion on the trends of habilitating technologies for Industry 4.0 and Smart manufacturing. Manufacturing Letters, 15: 60-63. Available: https://doi.org/10.1016/j.mfglet.2018.02.011

Aulbur, W., CJ, A. and Bigghe, R. (2016). Skill development for industry 4.0. Roland berger, BRICS skill development working group, india section. 1-50. Available: http://www.globalskillsummit.com/Whitepaper-Summary.pdf

Austrialia Industry Group (2018). Soft Skills for Industry 4.0 (The Digital Age) - An Introduction. The Australian Industry Group. https://www.aigroup.com.au/training-and-events/soft_skills_industry_4_0

Benioff, M. R. (2017). We must ensure the Fourth Industrial Revolution is a force for good. World Economic Forum: 1-5. Available: https://www.weforum.org/agenda/2017/03/we-must-ensure-the-fourth-industrialrevolution-is-a-force-for-good/

Bermudez Milagros Diaz, 2017. "Competencies to adopt Industry 4.0 for operations management personnel at automotive parts suppliers in Nuevo Leon." In Proceedings of the International Conference on Industrial Engineering and Operations Management Bogota, Volombia. pp. 736-47.

Chuah, L. L., Loayza, N. V. and Schmillen, A. D. (2018). Research and policy briefs from the world bank malaysia hub the future of work: Race with - not against - the machine. The World Bank Group.

Dahalan, H. (2016). When push come to shove for technology. Malaysian Technology Development Organization: $1-6$.

Davies, A., Fidler, D. and Gorbis, M. (2011). Future work skills 2020. Institute for the Future. https://doi.org/10.13140/RG.2.1.3839.4721

Fantini, P., Pinzone, M. and Taisch, M. (2018). Placing the operator at the centre of Industry 4.0 design: Modelling and assessing human activities within cyber-physical systems. Computers and Industrial Engineering: 139. Available: https://doi.org/10.1016/j.cie.2018.01.025

Ger, M. (2018). Open-source data management for industry 4.0 - dzone iot. Dzone. Available: https://dzone.com/articles/open-source-data-management-for-industry-40

Grzybowska, K. and Łupicka, A. (2017). Key competencies for Industry 4.0.: 250-53. Available: https://doi.org/10.26480/icemi.01.2017.250.253

Hecklau, F., Galeitzke, M., Flachs, S. and Kohl, H. (2016). Holistic approach for human resource management in industry 4.0. . Procedia CIRP, 54: 1-6. Available: https://doi.org/10.1016/j.procir.2016.05.102

Hendrick, D. (2017). The 10 critical job skills of the future, according to Mckinsey's global chief learning officer, darden report online. Univerity of Virginia: Daren School of Business. https://news.darden.virginia.edu/2017/09/21/10-critical-job-skills-of-the-future/

Hrdy, C. A. (2018). Technological unemployment. University of Akron School of Law.

Karre, H., Hammer, M., Kleindienst, M. and Ramsauer, C. (2017). Transition towards an industry 4.0 state of the Leanlab at Graz University of Technology. Procedia Manufacturing, 9: 206-13. Available: https://doi.org/10.1016/j.promfg.2017.04.006 
Leong, L. M. and Kasmuri, A. (2017). Why should Malaysia focus on Industry 4.0? Iskandar Regional Development Authority, 9: 3. Available: http://iskandarmalaysia.com.my/wp-content/uploads/2017/10/IM-BizWatchSeptember-2017.pdf

Matthiae, M. and Richter, J., 2018. "Industry 4 .0. Induced change factors and the role of organizational agility." In Twenty-Sixth European Conference on Information Systems (ECIS2018).

Michael, C., James, M. and M, M. (2016). Where machines could replace humans--and where they can't (yet). McKinsey and Company. https://www.mckinsey.com/business-functions/digital-mckinsey/ourinsights/where-machines-could-replace-humans-and-where-they-cant-yet

MITI (2018). Industry 4wrd, national policy on industry 4.0. Ministry of international trade and industry. Available: https://www.miti.gov.my/miti/resources/NationalPolicyonIndustry4.0/Industry4WRD_Final.pdf

MTDC (2013). The book of journeys Malaysian Technology Development Corporation.

MTDC Press Release (2018). MTDC sets up Centre of 9 Pillars (Co9P) and extends partnership with Industry 4.0 Partners (p. 5). Available: https://emag.live/mtdc-sets-up-centre-of-9-pillars-co9p-and-extends-partnershipwith-industry-4-0-partners/

Mustafa, Z. (2018). Preparing for industry 4.0 with leadership skills. New Strait Times. https://www.nst.com.my/education/2018/03/347558/preparing-industry-40-leadership-skills

Pfeiffer, S. (2017). The vision of "industrie 4.0" in the making - a case of future told, tamed, and traded. NanoEthics, 11(1): 107-21. Available: https://doi.org/10.1007/s11569-016-0280-3

Prifti, L., Knigge, M., Kienegger, H. and Krcmar, H. (2017). A competency model for “industrie 4 .0” employees. 46-60.

Rojko, A. (2017). Industry 4.0 concept: Background and overview. International Journal of Interactive Mobile Technologies (IJIM), 11(5): 77. Available: https://doi.org/10.3991/ijim.v11i5.7072

Schroeder, W. (2016). Germany's Industry 4.0 strategy Rhine capitalism in the age of digitalisation. Friedrich Ebert Stiftung: 0-16. Available: https://doi.org/10.1109/SCSP.2016.7501015

Sivathanu, B. and Pillai, R. (2018). Smart HR4.0 - How Industry 4.0 is disrupting HR. Human Resource Management International Digest, 26(4): 7-11. Available: https://doi.org/10.1108/HRMID-04-2018-0059

The Edge (2018). MTDC wants local companies to hasten Industry 4.0 preparations | KLSE Screener. The Edge. Available: https://www.klsescreener.com/v2/news/view/397877/mtdc-wants-local-companies-to-hastenindustry-4-0-preparations

Wang, B. (2018). The future of manufacturing: A new perspective. Engineering: Available: https://doi.org/

WEF Report (2018). The Future of Jobs Report 2018 Insight Report. Available: https://doi.org/10.1177/1946756712473437

World Economic Forum (2017). Technology and innovation for the future of production: Accelerating value creation. World economic forum white paper. Available: http://www3.weforum.org/docs/WEF_White_Paper_Technology_Innovation_Future_of_Production_2017. pdf

Xu, M., David, J. M. and Kim, S. H. (2018). The fourth industrial revolution: Opportunities and challenges. International Journal of Financial Research, 9(2): 90. Available: https://doi.org/10.5430/ijfr.v9n2p90 